Portland State University

PDXScholar

Master of Environmental Management Project

Reports

Environmental Science and Management

Fall 2006

\title{
Koll Center Wetlands Natural Resources \\ Maintenance Management Plan
}

Meredith Clayton

Portland State University

Follow this and additional works at: https://pdxscholar.library.pdx.edu/mem_gradprojects

Part of the Natural Resources and Conservation Commons, Natural Resources Management and Policy Commons, and the Water Resource Management Commons Let us know how access to this document benefits you.

\section{Recommended Citation}

Clayton, Meredith, "Koll Center Wetlands Natural Resources Maintenance Management Plan" (2006).

Master of Environmental Management Project Reports. 4.

https://pdxscholar.library.pdx.edu/mem_gradprojects/4

https://doi.org/10.15760/mem.34

This Project is brought to you for free and open access. It has been accepted for inclusion in Master of Environmental Management Project Reports by an authorized administrator of PDXScholar. Please contact us if we can make this document more accessible: pdxscholar@pdx.edu. 


\section{Table of Contents}

\section{SECTION}

PAGE

Overview

2

Information for Plan Users

How To Use This Plan

All Employees

How This Plan Was Created

Reviewing and Modifying This Plan

Relationship to Other Documents

Natural Area Maintenance Principles

Habitat Management

Aquatic and Wetland Habitats $\quad 10$

Aquatic Habitats 10

SP1 10

$\underline{\text { SI1 }} 12$

Palustrine Emergent Wetland $\quad 13$

PEW1 13

PEW2 14

Upland Habitats 16

Mixed Forests

MF1 16

Physical Asset Management $\quad 18$

Easements and Rights of Ways $\quad 18$

Water Management Structures $\quad 20$

Appendix A - Glossary 21

Appendix B - Habitat Classification Codes 22

Appendix C - Maps 23

C-1 Habitat 23

C-2 Physical Assets 24

C-3 Enhancement Planting Plan 25

C-4 Blackberry Removal Strategy 26

Appendix D - Activity Spreadsheets 27

Appendix E - Best Management Practices 28 


\title{
Koll Center Wetlands Natural Resources Maintenance Management Plan
}

\author{
Meredith Clayton \\ MEM-2006
}


Koll Center Wetlands

November 2006 


\section{Koll Center Wetlands}

\section{Natural Resources Maintenance Management Plan}

\section{Overview}

Back to Top

The intention of this plan is to provide a vision and guidelines for maintaining and improving the ecological health of Koll Center Wetlands in the short and long term. Although the plan will change over time, the goal is to quantify natural resource needs spatially, temporally, and economically.

Koll Center Wetlands is part of the Greenway/Fanno Creek/Koll Center Wetlands Park complex. The nearly 13 acre park is dominated by aquatic habitats that attract a wide variety of wildlife, particularly birds. The park grounds are not easily traversed and experience limited human use, but there are many viewpoints from which the park is easily and commonly observed by visitors.

The park serves as valuable habitat for both local and migratory wildlife as it connects with the many other terrestrial and aquatic habitats of the park complex, forming a large wildlife corridor in an otherwise urban setting. The aquatic habitats respond to fluctuating water levels, creating seasonally diverse habitat conditions that support a variety of birds, mammals, and reptiles. A mixed forest grows on the southern slope of the park, housing a heron rookery and many wellestablished oaks and conifers.

A weir located just past the south border of the property enables the wetlands to provide the services of storm detention and water filtration for runoff from the surrounding business park. Runoff from parking lots and landscaped areas can contain contaminants and nutrients capable of jeopardizing stream health. Settling and filtration of these compounds occurs as water travels north to south in the wetland, making the water that ultimately reaches Fanno Creek cleaner than it began.

Since Koll Center Wetlands is located within a highly urbanized area, direct and indirect impacts to the natural areas from the surrounding region are considered in the maintenance management plan (MMP) for the park and its individual habitat units. These include, but are not limited to, direct human impacts, invasive plants and animals, and ongoing natural processes in plant communities.

The key outcomes of this plan include the following:

\section{Significant Changes}

- A change to active management of water levels. Drawdown of the wetlands will begin earlier, creating new mudflats and foraging habitat throughout the summer months. This is recommended in order to increase habitat diversity, which will increase the presence of desirable species in the wetlands. Planting native vegetation is also recommended to prevent the spread of non-native species into newly exposed areas. 


\section{Routine Management}

- A decision to allow natural processes to occur in most natural areas. This means that many natural areas of the park would be left for plants and wildlife to grow, as long as non-native weeds are not interfering with natural processes.

- Systematic removal and containment of non-native plant populations. Non-native plants are a dominant presence in most habitats at Koll Center and should be replaced by native vegetation where feasible. Specifically, Himalayan blackberry will be targeted for removal from the MF1 habitat over a 6-year span. In PEW1 and PEW2, efforts should focus on preventing the spread of reed canarygrass monocultures. 


\section{Information for Plan Users}

How To Use This Plan

Back to Top

1. Read overview of park and natural area maintenance principles sections.

2. Determine maintenance activity AND/OR habitat unit you will be working in. This includes a review of the habitat units map.

3. Find information about the activity or habitat using both the index and map.

4. Read information about the activity needed. (Note that a glossary is in the back of this document.)

5. Read and follow associated Best Management Practice (BMP) and reference documents to carry out activity.

\section{All Employees}

Back to Top

Reading this manual is part of your training. It will help you learn what to do, how to do it, and why what you're doing is important. Before you begin new tasks, you should walk Koll Center Wetlands and attempt to match the locations and information in this plan with the places it describes. The map of the various habitat units will be of great value when working in the park. Do not hesitate to ask for clarification if you have any questions about this Plan.

\section{How This Plan Was Created}

Back to Top

A natural resource inventory of the park was created by finding the edges of different habitat units, mapping them, and doing a walking transect through the unit where vegetation and habitat information was recorded. Each habitat was categorized and assigned a code. These coded areas are hereafter called habitat units. Detailed information from this inventory can be found in the District's Natural Resources office. The inventory was used to determine the maintenance and management activities described in this plan.

Koll Center Wetlands Maintenance Management Plan was created by Portland State University graduate student Meredith Clayton and Natural Resources staff members Bruce Barbarasch and Kyle Spinks. Staff consulted Koll Center Wetlands original development plans and records, made field observations, and interviewed THPRD staff as well as colleagues from other agencies about practices, procedures, and time standards. These items were integrated with the natural resources inventory of Koll Center Wetlands. The plan was circulated to other Departments for feedback, after which THPRD Management Staff ultimately reviewed and approved this plan.

\section{Reviewing and Modifying This Plan}

Back to Top

This document is intended to be modified. Nature changes and grows with time and the plan should, too. On the other hand, changes should not be arbitrary; suggestions for change should be supported by two scientific or commonly accepted sources. The plan should be reviewed every three years, but minor adjustments or additions to this document can be made by submitting suggestions to the Natural Resources Supervisor. Modifications will be reviewed annually and must be approved by the Natural Resources Supervisor and the Superintendent of Special Programs and Activities. 
Koll Center Wetlands

November 2006

Relationship To Other Documents

Back to Top

This plan relates to the following Tualatin Hills Park and Recreation District (THPRD) or regional plans, which can be found in the Natural Resources office:

o THPRD Natural Resources Management Plan

o THPRD Best Management Practices

o THPRD 20-year Comprehensive Plan

o THPRD Integrated Pest Management Policy

o THPRD/Washington County Department of Health - West Nile Virus Program

o National Vegetation Classification System (NVCS)

o Classification of Wetlands and Deepwater Habitats of the United States 


\section{Natural Area Maintenance Principles}

Back to Top

Historically, natural areas have been viewed as places that take care of themselves. It is now understood that this is not the case in urban areas. ${ }^{1}$ Without active management of outside influences, natural areas will lose their native biological diversity over time as a result of human activities and invasion by non-native species. Although maintenance activities must be done in these areas, the approach is considerably different than maintaining a traditional, turf-oriented park.

The purpose of natural area maintenance is to lessen human impacts and allow natural processes to continue, while providing safe access for humans where appropriate. Suggested natural area maintenance activities include removing non-native weeds, planting native plants, decommissioning/obscuring unwanted demand trails, and pruning vegetation away from trails. Leaves should be left on the ground to enrich the soil; standing dead trees and logs are both acceptable and beneficial when located a safe distance from a trail.

Unlike within a developed park where clean edges and neatly trimmed bushes are desirable, natural area maintenance activities may not be obvious to visitors. For example, where shrubs need to be trimmed back from a trail through a natural area, care should be taken to maintain the illusion that the trail clearings are not artificially created. On the other hand, removal of invasive weeds such as Himalayan blackberry will temporarily leave a very obvious empty space until the area is replanted.

According to THPRD's Natural Resources Management Plan, the goal of habitat management (and maintenance) is to work toward healthy natural systems. To that end, rather than building physical structures, it is preferable to plant native vegetation that will become habitat. Instead of installing bird or bat boxes, which require ongoing human maintenance, plant trees that will one day become homes for wildlife. Planting shrubs to keep visitors on trails is preferable to building a fence.

While most of the information described in this plan is geared towards parks that have large natural areas which are dominated by native plants and natural processes, some developed parks have natural features in them. Natural features are generally small natural areas, native plants within a developed landscape, or water features like Commonwealth Lake that have both natural and recreational uses. Maintenance of natural features combines traditional and natural resource maintenance techniques.

The Best Management Practices found on the Inside THPRD website describe the proper way to perform maintenance activities in natural areas and around natural features.

\footnotetext{
${ }^{1}$ Godefroid, S. and N. Koedam. 2003. Distribution pattern of the flora in a peri-urban forest: an effect of the cityforest ecotone. Landscape and Urban Planning. 65, 169-185.
} 


\section{Background}

In a natural system, plant communities go through cycles where one vegetation community comes to dominate an area, and then as conditions change, other plants grow in number, size, and density. The process where one plant community replaces another is often called succession. While this is never an entirely orderly or predictable process, changes are common and expected. Some changes are rapid, while most take place over many decades or centuries. For example, although it is considered an early successional species, Douglas-fir trees can live for up to 750 years, ${ }^{2}$ and often are the dominant trees in old-growth forests. Other species such as western hemlock, which may become the next successional dominant in a forest, may not be appear as seedlings until Douglas-fir trees are 50 to 100 years old. ${ }^{3}$ Because urban natural areas do not have all the parts of larger and more "wild" natural habitats, the term "natural processes" will be used in this document instead of succession. For example, large mammals and innumerable smaller organisms, which may help spread seeds or eat certain plants, are missing from urban forests. Natural processes are still happening, but they are not equivalent to the successional processes that happen outside the urban environment.

In urban greenspaces, non-native weeds often become established, thus much of the habitat management described in this plan involves the removal and/or control of non-native plants. Many of the natural areas described in this plan are moderately to highly invaded with nonnative plants, ranging from small annual herbs to dominant trees in the forested sections of the park. The "maintenance" of these weeds will range from minor projects targeting removal of individual patches of non-native species to large-scale efforts to control many non-native species throughout the park.

A key part of the management and maintenance is monitoring. Monitoring includes regularly observing and recording changes to habitat areas, as well as recording maintenance and restoration activities on individual projects. The type of monitoring of both the small- and largescale projects will vary, though the overarching goal of this monitoring is to collect information that will allow adaptive management of the natural areas.

\section{Koll Center Wetlands}

Koll Center Wetlands is a palustrine emergent marsh. Water enters the wetland via precipitation, runoff, and two groundwater pumping wells. Peak water levels generally occur in early spring and decline through the summer, but rarely dry out completely due to water impounded by the weir. The clay soils present at the Wetlands limit infiltration and are inundated or saturated for most of the year. Vegetation at Koll Center Wetlands is dominated by plants classified with a facultative (FAC) or greater preference for wetland habitat. A diversity of native trees, shrubs, herbs, sedges, rushes, and floating plants are found at the Wetlands, that may be threatened due to increasing levels of cover by non-native grasses and shrubs. Koll Center Wetlands also provides habitat to numerous bird, reptile, amphibian, and mammal species. See Appendix C-1 for a map of habitats located within the park.

\footnotetext{
${ }^{2}$ Cascade-Olympic Natural History. A Trailside Reference., Daniel Matthews, 1988.

${ }^{3}$ Natural Vegetation of Oregon and Washington. Franklin, Jerry F., and C. T. Dyrness, 1988
} 
Non-native plants have a dominant presence in many of the habitats at Koll Center Wetlands. Reed canarygrass and velvetgrass are prevalent in the palustrine emergent wetlands and Himalayan blackberry comprises much of the understory cover in the mixed forest. These species outcompete native vegetation and decrease species- and habitat-level diversity. Nonnative plant populations should be prevented from expanding using the best management practices outlined by THPRD Best Management Practices or those created by The Nature Conservancy.

Non-native animals present at Koll Center Wetlands (nutria, bullfrogs, and snapping turtles) threaten native vegetation, amphibians, and reptiles. It is unlikely that nutria and bullfrogs could be successfully eliminated due to the connectivity of the Wetlands with Fanno Creek. Thus, there is currently no active management for these species. However, a trapping program has been successful in reducing breeding snapping turtle populations in the Wetlands. Trapping is initiated by turtle sightings and traps are monitored for 30 consecutive days. The setting and monitoring of traps is performed by Natural Resources Staff, and previous to 2007 was performed yearly. Beginning in the summer of 2007, trapping will be performed only every three years. The goal of this program is to reduce populations to a level where trapping will be done only on an “as-needed” basis after 2016.

Koll Center Wetlands is in close proximity to the industrial facilities at Hall and Cascade Boulevards where View-Master toys were produced beginning in 1950. An environmental assessment of the View-Master site in 1998 revealed significant contamination of groundwater by TCE and cyanide, both used in the production of the toys. Oregon Department of Environmental Quality (DEQ) prepared an ecological risk assessment focused on Koll Center Wetlands and Fanno Creek. Only cyanide was found to pose a threat to the surface water habitat, primarily to fish. However, large fish populations are not found within Koll Center Wetlands due to the weir at the confluence of the wetlands and Fanno Creek. DEQ found no evidence of stressed vegetation, birds, or other organisms as a result of the groundwater contamination.

Oregon DEQ currently pumps and treats groundwater from the View-Master site in two locations that discharge into Koll Center Wetlands. The larger remediation system is located at the north end of the wetlands and discharges 200 gpm of effluent. The smaller system is located along the drainage ditch that feeds into Fanno Creek and discharges $5 \mathrm{gpm}$. Maximum TCE and cyanide levels for the effluent are approximately 1/1,000th of the standard for aquatic health.

The following table lists the habitat classifications and habitat codes used in this document. With the exception of the Open Water designation, all codes are based upon the National Vegetation Classification Standard (NVCS) and will be substituted for the classification codes used in the inventory files prior to 2006. For all habitat labels in this document, the current habitat classification code is listed, followed by a habitat name (if one exists), then by the original classification code in brackets [ ]. See Appendix B for full list of classification codes used to designate THPRD natural areas. 
Koll Center Wetlands

November 2006

\begin{tabular}{|l|c|l|}
\hline \multicolumn{1}{|c|}{ Habitat Name } & $\begin{array}{c}\text { Current Classification } \\
\text { Code }\end{array}$ & \multicolumn{1}{c|}{$\begin{array}{c}\text { Original Classification } \\
\text { Code }\end{array}$} \\
\hline Palustrine Emergent Wetland & PEW & WM - Wetland Meadow \\
\hline Mixed Forest & MF & UMF - Upland Mixed Forest \\
\hline Stream Intermittent & SI & OW - Open Water \\
\hline Stream Perennial & SP & OW - Open Water \\
\hline
\end{tabular}


Aquatic and wetland habitats are dominated by water and its effects.

Most aquatic habitats such as ponds and streams contain water throughout the year, although some intermittent streams or ponds contain water only for a majority of the year. These habitats are considered aquatic, not wetlands because of the types of vegetation that are present.

In general, wetlands have standing water or soggy ground from December through May, depending on rainfall, though they may not be connected to streams. Most natural wetlands in the Tualatin Basin dry out completely during the late summer months. Wetlands also have unique soil conditions and a unique set of plants that are adapted to wet conditions.

Wetlands are a habitat conservation priority in the Willamette Valley mostly due to impacts from agricultural activities and urban development ${ }^{4}$. As demand for buildable land has increased, wetlands have been filled to make way for housing, retail stores and industrial complexes. The wetlands within our parks are of increased value because of their considerable size in comparison to the small bioswales and mitigation sites that are the result of continuing development in the region. Wetland habitats currently existing within the park's boundaries should be considered a valuable resource. Cutting of native waterside vegetation should be considered on a case-bycase basis, with an eye toward preserving (or restoring) the native integrity of the riparian area where ever possible. Safety concerns with regard to visibility should be resolved by rerouting of trails rather than cutting conservation resources. These resources should be viewed from a distance in order to be respected as valuable and preserved for the future.

\section{Aquatic Habitats}

Back to Top Aquatic habitats have flowing or standing water year-round and are dominated by plants that grow on or below the surface of the water for most of the growing season in most years. In some cases, you may not observe any plants growing in the water. Aquatic habitats boundaries are noted by the bankfull stage (this is the water level where any further addition of water will result in water moving out into the floodplain or surrounding habitats).

\begin{tabular}{|l|l|}
\hline $\begin{array}{l}\text { Habitat unit } \\
\text { description }\end{array}$ & $\begin{array}{l}\text { This is to Top dominant habitat unit of Koll Center Wetlands, comprising } \\
\text { over 50\% of the park. SP1 is a man-made area created to provide } \\
\text { detention and filtration for drainage from the surrounding business park. } \\
\text { Water travels in a southwesterly direction, entering predominantly from } \\
\text { an upland drainage on the east side of the property. The habitat } \\
\text { boundaries are gently sloped banks; as a result, water levels and } \\
\text { boundaries can change dramatically from winter to summer. Water is } \\
\text { generally shallow throughout, but may be above } 6 \text { feet in some places. } \\
\text { Water depth is maintained by a weir structure with permanently affixed } \\
\text { boards near the confluence of the wetland with Fanno Creek. Despite the } \\
\text { weir, evapotranspiration causes a natural drawdown of the wetlands } \\
\text { beginning in July, forming mudflats in shallow areas. Some open water }\end{array}$ \\
\hline
\end{tabular}

${ }^{4}$ 2003-2007 Oregon Statewide Comprehensive Outdoor Recreation Plan. Appendix L: Oregon Wetlands Priority Plan. January 2003. www.oregon.gov/OPRD/PLANS/docs/scorp/scorp_21_appl.pdf. 


\begin{tabular}{|c|c|}
\hline & $\begin{array}{l}\text { habitat is maintained throughout the summer. Canopy closure is minimal } \\
\text { throughout the habitat. }\end{array}$ \\
\hline $\begin{array}{l}\text { Natural resource } \\
\text { areas of concern }\end{array}$ & $\begin{array}{l}\text { - Natural areas } \\
\text { o Specific plants: None. } \\
\text { o Natural structures: None. } \\
\text { o } \text { Water resources: Perennial stream. } \\
\text { o Wildlife: Non-native snapping turtles. } \\
\text { - Modified natural areas } \\
\text { o } \\
\text { Easements \& Rights of way: Sewer access, GAF Corp. } \\
\text { o } \text { maintenance access, and water treatment agreement*. } \\
\text { Man-made features } \\
\text { o Recreational structures: None. } \\
\text { o Trail features: None. } \\
\text { o Turfed areas: None. } \\
\text { o Water management structures: Weir in south channel that } \\
\text { meets Fanno Creek. }\end{array}$ \\
\hline $\begin{array}{l}\text { Long-term vision of } \\
\text { habitat units }\end{array}$ & $\begin{array}{l}\text { A water management plan that begins drawdown in June is recommended, } \\
\text { allowing for more active habitat management in the wetlands. Beginning } \\
\text { in June, one board (6 inches in height) would be removed at a time from } \\
\text { the weir in order to facilitate a slow and steady drawdown through } \\
\text { September. The boards are to be replaced when steady rain begins in } \\
\text { autumn. This process should provide sufficient open water habitat to } \\
\text { maintain an acceptable level of runoff detention and treatment before the } \\
\text { waters enter Fanno Creek. The proposed June drawdown will decrease } \\
\text { the amount of aquatic habitat earlier in the summer, which may decrease } \\
\text { habitat suitability for invasive snapping turtles and increase trapping } \\
\text { effectiveness. Due to the shallow and gently sloping margins of the } \\
\text { wetland, even a small drop in water level can expose a large area of } \\
\text { substrate. Thus, the new drawdown plan will also expose a larger mudflat } \\
\text { areas in the shallow margins of SP1, increasing structural diversity within } \\
\text { the wetlands as a whole. } \\
\text { Anchoring of large woody debris in shallow margins of the water will } \\
\text { enhance habitat for a variety of species in the wetlands. Woody debris } \\
\text { such as logs would provide substrate and cover for aquatic insect } \\
\text { populations, which would then provide feeding sites for organisms that } \\
\text { feed upon the insects. Woody debris would also provide perching sites } \\
\text { for birds and basking sites for native turtles. }\end{array}$ \\
\hline
\end{tabular}

\footnotetext{
* Refer to page 19 for more details on this agreement
} 


\begin{tabular}{|l|l|}
\hline $\begin{array}{l}\text { Desired } \\
\text { maintenance } \\
\text { activities }\end{array}$ & None. \\
\hline $\begin{array}{l}\text { Reference } \\
\text { Documents }\end{array}$ & Greenway Park MMP. OWEB Grant Proposal. \\
\hline
\end{tabular}

\begin{tabular}{|c|c|}
\hline & SI1 - [OW2] Back to Top \\
\hline $\begin{array}{l}\text { Habitat unit } \\
\text { description }\end{array}$ & $\begin{array}{l}\text { This is an intermittent stream that drains storm water from the } \\
\text { surrounding business park and MF1 into SP1 along the east side of the } \\
\text { park. Red alder dominates tree cover and canopy closure over the stream } \\
\text { is } 60 \% \text {. }\end{array}$ \\
\hline $\begin{array}{l}\text { Natural resource } \\
\text { areas of concern }\end{array}$ & $\begin{array}{l}\text { - Natural areas } \\
\text { o } \text { Specific plants: None. } \\
\text { o Natural structures: None. } \\
\text { o Water resources: Intermittent stream. } \\
\text { o Wildlife: None. } \\
\text { - Modified natural areas } \\
\text { o Easements \& Rights of way: None. } \\
\text { o } \quad \text { Restoration/mitigation sites: None. } \\
\text { - Man-made features } \\
\text { o Recreational structures: None. } \\
\text { o Trail features: None. } \\
\text { o Wurfed areas: None. }\end{array}$ \\
\hline $\begin{array}{l}\text { Long-term vision of } \\
\text { habitat units }\end{array}$ & Allow natural processes to proceed in this area. \\
\hline $\begin{array}{l}\text { Desired } \\
\text { maintenance } \\
\text { activities }\end{array}$ & Monitor stream for erosion. \\
\hline $\begin{array}{l}\text { Reference } \\
\text { Documents }\end{array}$ & None. \\
\hline
\end{tabular}


Palustrine Emergent Wetland (PEW) is characterized by erect, rooted, herbaceous hydrophytes, excluding mosses and lichens. This vegetation is present for most of the growing season in most years. Perennial plants usually dominate these wetlands. All water regimes are included except subtidal and irregularly exposed. (NVCS = Temperate Perennial Graminoid Vegetation, Temperate Perennial Forb Vegetation (e.g., reed canarygrass/soft rush)).

Most of these wetlands are monitored as part of the District's West Nile Virus monitoring program. At this point in time, they are not treated with anti-mosquito products. Treatment is done by trained Maintenance staff in collaboration with the Natural Resources Supervisor. See the West Nile Virus Program notebook for more details.

\begin{tabular}{|c|c|}
\hline & PEW1 - [WM1] \\
\hline $\begin{array}{l}\text { Habitat unit } \\
\text { description }\end{array}$ & $\begin{array}{l}\text { This unit represents the emergent wetland on the west side of the site. } \\
\text { The habitat is bordered by SP1 to the east, Greenway Park to the west, } \\
\text { and paved parking to the north. This habitat may be completely flooded in } \\
\text { the winter months and exposed in the summer. Reed canarygrass forms a } \\
\text { tall monoculture in the summer months where PEW1 borders SP1. A less } \\
\text { dense mix of native and non-native, emergent, herbaceous, and shrubby } \\
\text { vegetation can be found to the west. Small alders and pines scatter the } \\
\text { westernmost edge of this habitat and a few willows are present in the } \\
\text { northeast strip, but canopy closure is minimal. In some places, } \\
\text { ornamentals like red osier dogwood have dispersed from the parking areas } \\
\text { into the natural area. The interface between this habitat and SP1 provides } \\
\text { breeding habitat for reptiles and amphibians. }\end{array}$ \\
\hline $\begin{array}{l}\text { Natural resource } \\
\text { areas of concern }\end{array}$ & 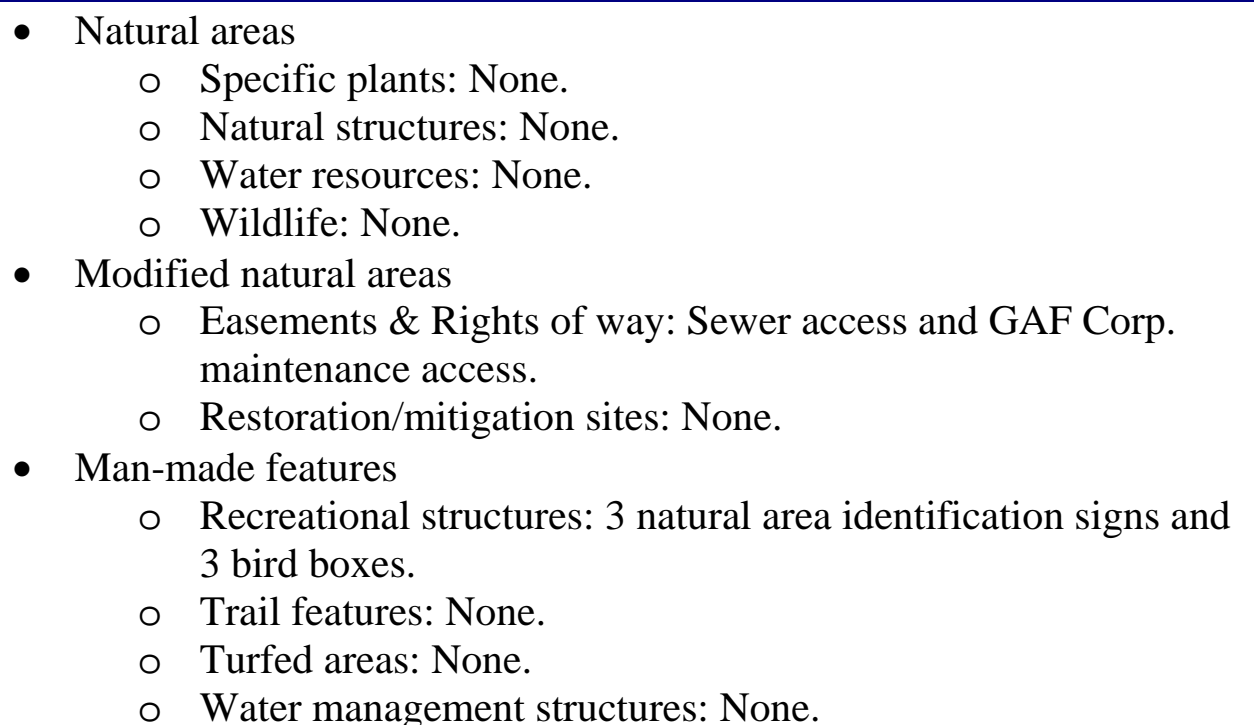 \\
\hline $\begin{array}{l}\text { Long-term vision of } \\
\text { habitat units }\end{array}$ & $\begin{array}{l}\text { Due to the shallow and gently sloping margins of the wetland, even a } \\
\text { small drop in water level can expose a large area of substrate. Thus, } \\
\text { planting emergent vegetation is recommended in the shallow margins of } \\
\text { the water where mudflats will develop under the new drawdown regime. } \\
\text { This vegetation should include native species of cattail, bulrush, and } \\
\text { sedge. These species will compete with well-established, non-native }\end{array}$ \\
\hline
\end{tabular}




\begin{tabular}{|c|c|}
\hline & $\begin{array}{l}\text { grasses as water levels recede. Emergent vegetation will provide } \\
\text { additional forage and shelter for desired birds, amphibians, reptiles, and } \\
\text { fish. Some open mudflat areas are desirable, however, to support existing } \\
\text { shorebird populations. Therefore, vegetation will not be planted in all } \\
\text { newly exposed areas. See Appendix C-3 for a proposed planting strategy. } \\
\text { Adding woody vegetation will provide nesting habitat for the diverse bird } \\
\text { community present at Koll Center Wetlands. Live woody vegetation is } \\
\text { also preferentially selected for egg-laying by native frogs, which are } \\
\text { desired at the site. By adding trees and shrubs along the north-central } \\
\text { bank of the wetland, viewpoints at established overlooks (along east and } \\
\text { southeast borders) will be not diminished due to plant growth. } \\
\text { Anchoring large woody debris in shallow margins of the water will } \\
\text { enhance habitat for a variety of species in the wetlands. Woody debris } \\
\text { such as logs would provide substrate and cover for aquatic insect } \\
\text { populations, which would subsequently provide feeding sites for the } \\
\text { organisms which feed upon the insects. Woody debris would also provide } \\
\text { perching sites for birds and basking sites for native turtles. } \\
\text { When bird boxes wear out, they will not be replaced. }\end{array}$ \\
\hline $\begin{array}{l}\text { Desired } \\
\text { maintenance } \\
\text { activities }\end{array}$ & Natural area sign maintenance. \\
\hline $\begin{array}{l}\text { Reference } \\
\text { Documents }\end{array}$ & OWEB Grant Proposal. \\
\hline
\end{tabular}

\begin{tabular}{|c|c|}
\hline & PEW2 - [WM2] \\
\hline $\begin{array}{l}\text { Habitat unit } \\
\text { description }\end{array}$ & $\begin{array}{l}\text { This area is comprised of a narrow strip of wetland edge habitat. The } \\
\text { habitat is } 5 \text { to } 35 \text { feet wide, bordered by SP1 on one side and paved } \\
\text { parking on the other. In some places, ornamentals from the parking areas } \\
\text { have dispersed into the natural area. This habitat may be completely } \\
\text { flooded in the winter months and exposed in the summer. Reed } \\
\text { canarygrass and cattail are dominant plants. The interface between this } \\
\text { habitat and SP1 provides breeding habitat for reptiles and amphibians. }\end{array}$ \\
\hline $\begin{array}{l}\text { Natural resource } \\
\text { areas of concern }\end{array}$ & $\begin{array}{l}\text { - Natural areas } \\
\text { o Specific plants: None. } \\
\text { o Natural structures: None. } \\
\text { o Water resources: None. } \\
\text { o Wildlife: None. } \\
\text { - Modified natural areas } \\
\text { o Easements \& Rights of way: Maintenance access and water } \\
\text { treatment agreement. } \\
\text { o Restoration/mitigation sites: None. } \\
\text { Man-made features } \\
\text { o Recreational structures: } 1 \text { natural area identification sign. }\end{array}$ \\
\hline
\end{tabular}




\begin{tabular}{|l|l|}
\hline \multirow{1}{*}{$\begin{array}{l}\text { Long-term vision of } \\
\text { habitat units }\end{array}$} & $\begin{array}{l}\text { o Trail features: None. } \\
\text { o Turfed areas: None. }\end{array}$ \\
& $\begin{array}{l}\text { Due to the shallow and gently sloping margins of the wetland, even a } \\
\text { small drop in water level can expose a large area of substrate. Thus, the } \\
\text { planting emergent vegetation is recommended in the shallow margins of } \\
\text { the water where mudflats will develop under the new drawdown regime. } \\
\text { This vegetation should include native species of cattail, bulrush, and } \\
\text { sedge. These species will compete with well-established, non-native } \\
\text { grasses as water levels recede. Emergent vegetation will provide } \\
\text { additional forage and shelter for desired birds, amphibians, reptiles, and } \\
\text { fish. Some open mudflat areas are desirable, however, to support existing } \\
\text { shorebird populations. Therefore, vegetation will not be planted in all } \\
\text { newly exposed areas. See Appendix C-3 for a proposed planting strategy. }\end{array}$ \\
$\begin{array}{l}\text { Anchoring large woody debris in shallow margins of the water will } \\
\text { enhance habitat for a variety of species in the wetlands. Woody debris } \\
\text { such as logs would provide substrate and cover for aquatic insect } \\
\text { populations, which would subsequently provide feeding sites for the } \\
\text { organisms that feed upon the insects. Woody debris would also provide } \\
\text { perching sites for birds and basking sites for native turtles. }\end{array}$ \\
$\begin{array}{l}\text { Natural area sign maintenance. } \\
\text { Desired } \\
\text { maintenance }\end{array}$
\end{tabular}




\section{Upland Habitats}

Back to Top

Upland habitats are characterized by their lack of standing water and/or saturated soils. These forests may be comprised wholly of deciduous trees, coniferous trees, or a mixture of these. Forest canopy heights are generally greater than $6 \mathrm{~m}$ (20 feet), though the canopy structure may be of one more or less a single height or may range in height, with smaller trees dominating the sub-canopy. Likewise, canopy closure may range from $20 \%$ up to $100 \%$.

Because of the lack of soil saturation, the suite of species that grow in upland habitats is noticeably different that other wetland habitats. Generally, the plants are able to withstand the droughty summers better than wetland species and the trees often have more extensive root systems than their wetland counterparts. Upland habitat soil characteristics, especially the chemical make-up of the topsoils, are also significantly different than wetland soils, typically having more organic matter and greater saturation capabilities. This also plays a role in determining which plant species grow in these habitats.

\section{Mixed Forest}

Back to Top

This habitat contains a heron rookery and many well-established deciduous and coniferous trees. This unit is part of a larger forested area that includes property not owned by THPRD. It is necessary to work cooperatively with the surrounding businesses and property owners to ensure the protection of these valuable resources.

\begin{tabular}{|c|c|}
\hline & MF1 - [UMF1] \\
\hline $\begin{array}{l}\text { Habitat unit } \\
\text { description }\end{array}$ & $\begin{array}{l}\text { This habitat is a mixed forest located in the southeast corner of the park. } \\
\text { It is bordered by SP1 to the northwest and paved parking and buildings } \\
\text { from all other angles. The forest grows on a slope that drains storm water } \\
\text { into the wetland from the business area above. SI } 1 \text { is the only } \\
\text { channelized flow coming down the slope and occurs at the northernmost } \\
\text { end of the habitat. Douglas fir forms the tallest canopy layers and an } \\
\text { intermediate canopy is dominated by white oak, red alder, and big-leaf } \\
\text { maple. Canopy cover ranges from } 50 \text { to } 90 \% \text {. The forest floor is } \\
\text { primarily covered by Himalayan blackberry, English ivy, and morning } \\
\text { glory. }\end{array}$ \\
\hline $\begin{array}{l}\text { Natural resource } \\
\text { areas of concern }\end{array}$ & 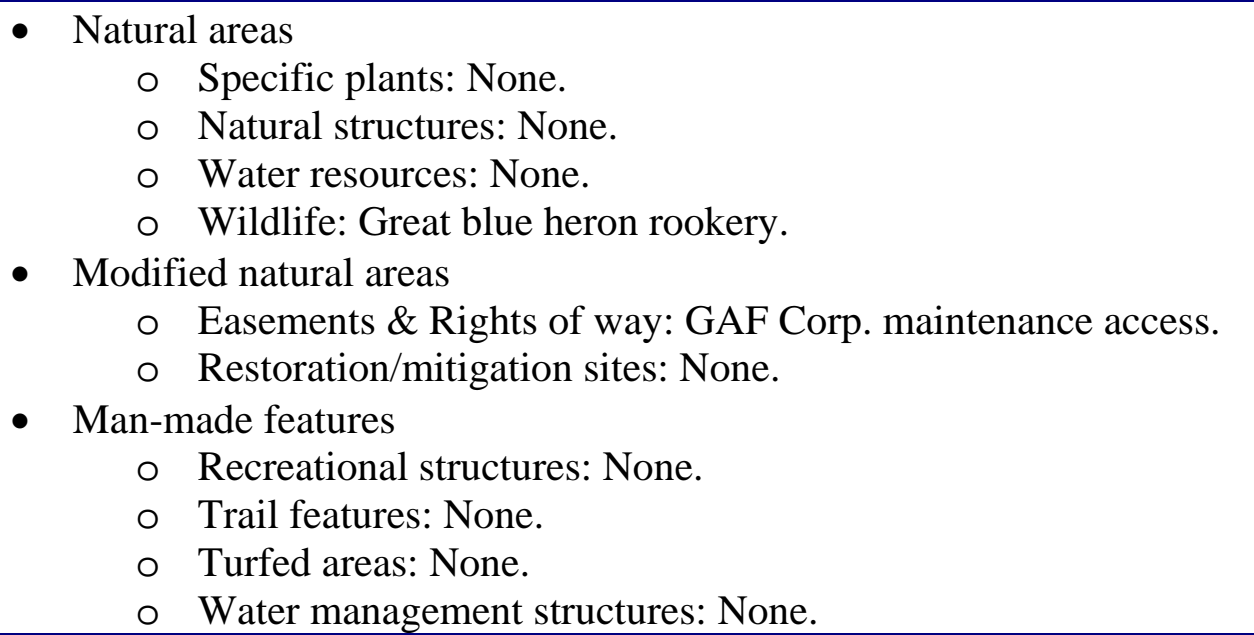 \\
\hline
\end{tabular}




\begin{tabular}{|l|l|}
\hline $\begin{array}{l}\text { Long-term vision of } \\
\text { habitat units }\end{array}$ & $\begin{array}{l}\text { Removal of Himalayan blackberry from MF1 is recommended. The 1.5 } \\
\text { acres of forested slope will be divided into 0.25-acre sections and one will } \\
\text { be cleared of blackberry each year, working north to south. See Appendix } \\
\text { C-4; clearing will begin in } 2008 \text { with section A and will be completed } \\
\text { with section F in 2013. Blackberry canes will manually removed in the } \\
\text { spring and chemically sprayed in the fall of the following two years. } \\
\text { Already established native understory shrubs will fill in many of the } \\
\text { spaces left open after blackberry removal, but planting of 200 native } \\
\text { shrubs per 0.25-acre section will help meet Clean Water Services density } \\
\text { requirements. Cut blackberry canes should be left onsite as mulch for } \\
\text { new plantings. } \\
\text { Great blue heron rookery should be protected, but with minimal } \\
\text { interference. Construction activities in the area should be avoided from } \\
\text { Feb 15 to July 31 while herons are nesting; this may require cooperation } \\
\text { from surrounding landowners. Great blue herons prefer very tall trees for } \\
\text { nesting, which are Douglas firs at Koll Center. Thus, these trees should } \\
\text { not be cut down and should be monitored for signs of disease during } \\
\text { natural resource routine inspections. The persistence of a heron rookery is } \\
\text { also dependent on the availability of food, therefore any management } \\
\text { changes that may significantly affect population numbers of insects, } \\
\text { amphibians, reptiles, fish, birds, and small mammals should include } \\
\text { consideration of the rookery. }\end{array}$ \\
\hline $\begin{array}{l}\text { Power tool cutting and brush treatment of Himalayan blackberry. } \\
\text { mesired } \\
\text { activities }\end{array}$ & \begin{tabular}{l} 
Himalayan blackberry BMP. \\
\hline Documents
\end{tabular} \\
\hline
\end{tabular}




\section{Physical Asset Management}

Back to Top

Physical assets like trails, signs, and bridges are essential to the educational and recreational mission of the Park District. Therefore, properly maintained assets encourage patrons to participate in low-impact activities while enjoying the natural areas, such as bird watching and walking/hiking. The items in this section are noted specifically because they may have a direct effect on natural resources; other traditional maintenance practices that do not have natural resource impacts are not listed.

Physical asset management is divided into the following sections:

\begin{tabular}{|l|c|c|}
\hline Asset Type & Present? & Impact to natural area? \\
\hline Easements \& Rights of Way & $\square$ & $\square$ \\
\hline Hazard Trees & $\square$ & $\square$ \\
\hline Recreational Structures & $\square$ & $\square$ \\
\hline Trail Features & $\square$ & $\square$ \\
\hline Turfed Areas & $\square$ & $\square$ \\
\hline Water Management Structures & $\square$ & $\square$ \\
\hline
\end{tabular}

Easements \& Rights of Way

Back to Top

An easement can be defined as, "a permanent land right acquired by a person or party to use the land or property of another for a special or particular purpose." ${ }^{5}$ Easement holders must be able to get access at any time. For example, if THPRD installs a gate, they must have a key to our lock or have their own lock on it.

Care must be taken not to install plants in these easements without permission. Any digging or other work that may affect these easements should be coordinated with the appropriate agencies holding the easement, though park staff may remove invasive plants from these areas without coordination with the easement holder(s). Many of the easements are periodically cleared by outside agencies; THPRD staff do not coordinate this. It is recommended that staff work closely with these agencies to meet both Natural Resources Department and agency objectives. The Natural Resources Supervisor will keep current contacts for these agencies.

Several easements for utilities run through Koll Center Wetlands.

\section{Sewer access}

Two sewer easements run through Koll Center Wetlands for buried conveyance lines. A storm sewer line runs along the full eastern length of the wetlands. A shorter section of sanitary sewer line crosses the northwest corner of the wetlands. The City of Beaverton is responsible for the maintenance of both sewer lines. The only vegetation cleared is that blocking access to the manholes. Because the sewer pipe is deeper than tree root zones, planting may be done anywhere in the vicinity of the sewer lines. See Appendix C-2 for sewer locations within the park.

\footnotetext{
${ }^{5}$ http://www.xcelenergy.com/docs/corpcomm/ROWQandA.pdf
} 


\section{Maintenance access}

THPRD has granted GAF Corporation access to Koll Center Wetlands by truck or on foot for the purposes of drilling, installation, maintenance, sampling, and related activities.

\section{Monitoring well access}

Two groundwater monitoring and remediation wells are present at Koll Center. One is located near the north end of the wetlands and the other is located in the southern channel that drains the wetlands into Fanno Creek. The easement for the monitoring wells is monitored and maintained by the Oregon Department of Environmental Quality.

\section{Water treatment agreement}

Koll Corporation holds an easement for use of the wetlands for the purposes of drainage and storm water management for the benefit of the surrounding commercial property. THPRD is required to encourage vegetation that maintains the filtering function of the wetlands in its management practices.

\section{Recreational Structures}

Back to Top

These features inform visitors and direct their activities into approved areas. In some cases, fencing and signage direct visitors away from areas that may be adversely impacted by visitors entering an area, such as a restoration site. Too many signs and fences are unsightly, so additional signage and/or fencing, and the placement locations, should be carefully considered. Only features and activities that directly impact natural are discussed in this document.

Few signs have been installed at Koll Center Wetlands. Two interpretive signs, located at the west and southeast ends of the wetlands, are not maintained by THPRD. However, THPRD is responsible for four yellow signs that identify the wetlands as a natural area and discourage offleash pets. See Appendix C-2 for sign locations within the park. The influence of water level fluctuation and preservation of the visual aesthetic at the wetlands are critical to sign placement and maintenance, so additional signage should be carefully considered.

\begin{tabular}{|l|l|l|}
\hline Task & \multicolumn{1}{l|}{ Natural area sign maintenance } \\
\hline $\begin{array}{l}\text { How to } \\
\text { do it }\end{array}$ & $\begin{array}{l}\text { Regular maintenance of plastic signs designating natural areas includes removing } \\
\text { graffiti, and replacing signs and hardware. }\end{array}$ \\
\hline Reason & Aesthetics, information to visitors. \\
\hline Who & Park Maintenance Tech \\
\hline Time & $\begin{array}{l}\text { Personnel spend approximately 0.5 hours on all signs for inspection. } \\
\text { Signs are evaluated for repair during routine inspection and for replacement every } 5 \\
\text { years. }\end{array}$ \\
\hline Number of times per month \\
\hline Jan \\
\hline-
\end{tabular}


Koll Center Wetlands

November 2006

Water Management Structures

Back to Top

Water management structures include weirs, culverts, dams, and other man-made devices meant to impound or channel water.

A weir structure maintained by THPRD is located on the tributary that feeds Fanno Creek from Koll Center Wetlands. This structure detains water in the wetlands in order to maintain habitat and filter runoff during the summer months. The weir has a metal frame with permanently affixed $4 \times 6$ inch boards. Planning for maintenance and/or replacement of this structure will need to consider the state regulations regarding fish passage. The weir is located in the Koll Center Wetlands Channel [SP 3] of Greenway Park; reference the Greenway Park MMP for weir inspection and maintenance practices. 


\begin{tabular}{|c|c|}
\hline Deciduous & Plants that lose their leaves each winter. \\
\hline Demand Trails & $\begin{array}{l}\text { Typically, natural surface trails created by park users in natural areas that } \\
\text { are not designed or maintained by District staff. }\end{array}$ \\
\hline Emergent & $\begin{array}{l}\text { Wetlands with plants such as cattails that are herbaceous and die back each } \\
\text { winter. The plants in these wetlands emerge from the water. These areas } \\
\text { may completely dry up during the summer. }\end{array}$ \\
\hline Evapotranspiration & $\begin{array}{l}\text { The conversion of water from liquid to vapor as a result of heat or use by } \\
\text { plants. }\end{array}$ \\
\hline Flashiness & $\begin{array}{l}\text { A quality of an urban stream where water levels rise very suddenly during } \\
\text { or shortly after a rain event due to runoff. }\end{array}$ \\
\hline Habitat & $\begin{array}{l}\text { Habitat refers to a specific community of plants and animals in nature. } \\
\text { Plants and animals find the basic things they need to survive in their } \\
\text { habitats. }\end{array}$ \\
\hline $\begin{array}{l}\text { Man-made } \\
\text { features }\end{array}$ & These include trails, power lines, sewers, buildings, signs, etc. \\
\hline Mitigation & $\begin{array}{l}\text { This is the process of restoring, enhancing or creating wetland habitat to } \\
\text { make up for an impact to a wetland that has occurred elsewhere. These } \\
\text { projects are often carried out by outside agencies with THPRD guidance on } \\
\text { our property. }\end{array}$ \\
\hline $\begin{array}{l}\text { Modified natural } \\
\text { area }\end{array}$ & $\begin{array}{l}\text { These areas differ from un-modified natural areas in that they have been } \\
\text { altered and restored by humans either as a result of construction, a } \\
\text { mitigation project, or other management that has placed some human } \\
\text { related restriction on the area. }\end{array}$ \\
\hline Natural area & $\begin{array}{l}\text { An area that is managed for the benefit of native plants and animals, which } \\
\text { receives minimal human intervention, except to lessen human impacts. }\end{array}$ \\
\hline Palustrine & $\begin{array}{l}\text { This a general term for freshwater, vegetated wetlands traditionally called } \\
\text { by such names as marsh, swamp, bog, fen, and prairie. }\end{array}$ \\
\hline Release & $\begin{array}{l}\text { By removing specific plant species that threaten to impact the growth of } \\
\text { other plant species, the tree is "released” to thrive. For example oak trees } \\
\text { can be released by removing ash trees growing near them. }\end{array}$ \\
\hline Replacement & $\begin{array}{l}\text { This is the process where one species of plant becomes dominant in an area } \\
\text { while another declines. It is not an active process that people participate in } \\
\text { (ex: "Hey, let's replace these Oregon grapes with thimbleberries.”) }\end{array}$ \\
\hline Restoration area & $\begin{array}{l}\text { An effort made in area to return it to a more natural state. This generally } \\
\text { involves removing non-native plants and replacing them with native plants } \\
\text { to re-create a natural area, but could also involve modification of slopes or } \\
\text { water resources. }\end{array}$ \\
\hline Riparian & The area along a stream or river that is home to many trees and shrubs. \\
\hline Woody debris & $\begin{array}{l}\text { Woody debris or woody matter is simply fallen trees and branches. It does } \\
\text { not include lumber or yard waste. }\end{array}$ \\
\hline
\end{tabular}




\section{Appendix B - THPRD Habitat Classification Codes}

Back to Top

\begin{tabular}{|l|c|l|}
\hline \multicolumn{1}{|c|}{ Name } & $\begin{array}{c}\text { New NVCS/Cowardin } \\
\text { Code }\end{array}$ & \multicolumn{1}{|c|}{ Old THPRD Code and Name } \\
\hline Palustrine Emergent Wetland & PEW & WM - Wetland Meadow \\
\hline Palustrine Shrubland & PS & WS - Wetland Scrub-Shrub \\
\hline Palustrine Forest & PF & WF - Wetland Forest \\
\hline Perennial Meadow & PM & Upland Meadow \\
\hline Deciduous Shrubland & DS & US - Upland Scrub-Shrub \\
\hline Deciduous Forest & DF & UDF - Upland Deciduous Forest \\
\hline Mixed Forest & MF & UMF - Upland Mixed Forest \\
\hline Evergreen Forest & EF & UCF - Upland Coniferous Forest \\
\hline Stream Intermittent & SI & OW - Open Water \\
\hline Stream Perennial & SP & OW - Open Water \\
\hline Pond & PO & OW - Open Water \\
\hline Modified Natural Area & MN & MN - Modified Natural Area \\
\hline Non-Natural Area & NN & NN - Non-Natural Area \\
\hline
\end{tabular}


Koll Center Wetlands

November 2006

Appendix C-1 - Habitat Map

Back to Top
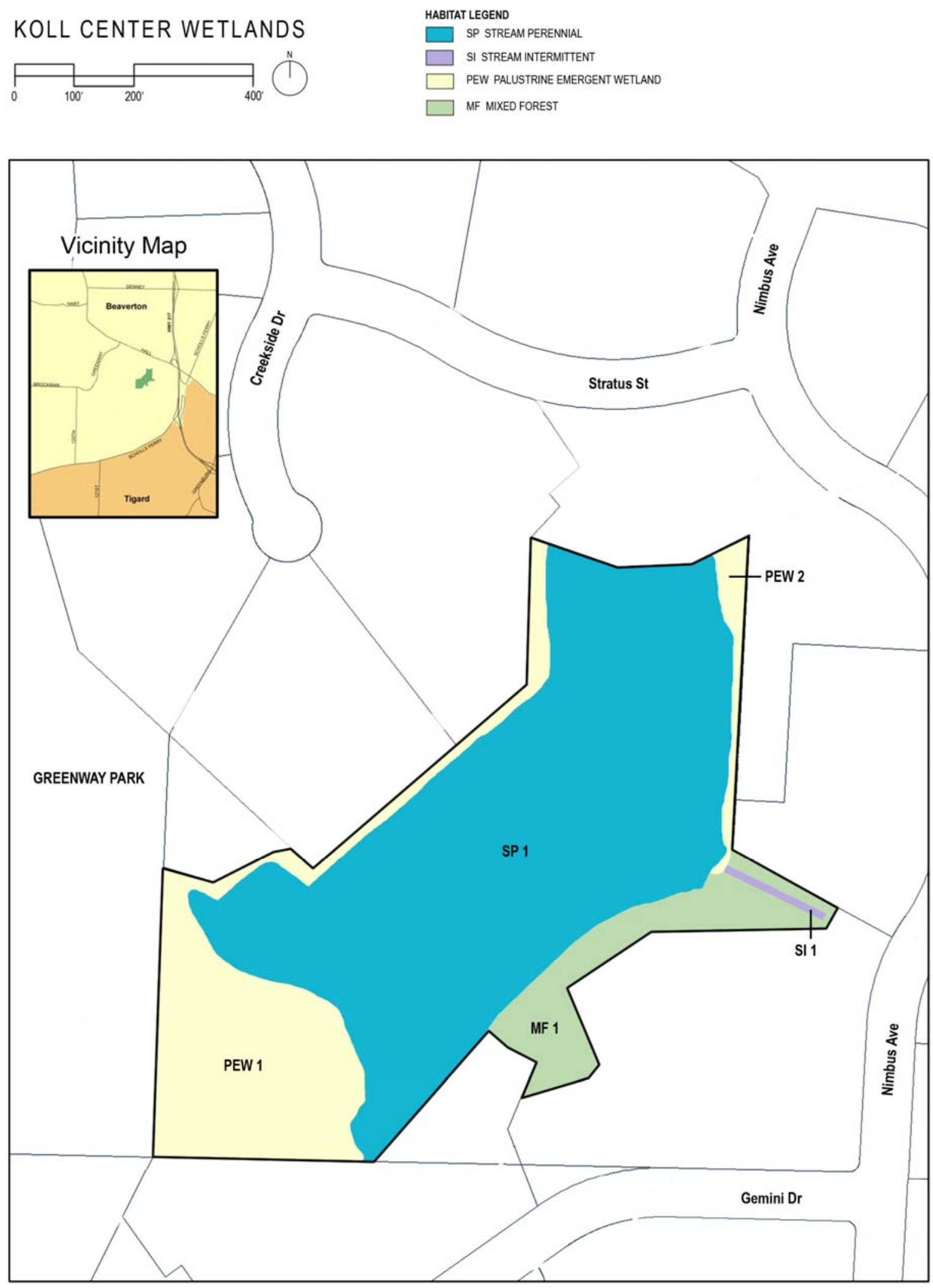
Koll Center Wetlands

November 2006

\section{Appendix C-2 - Physical Assets Map}
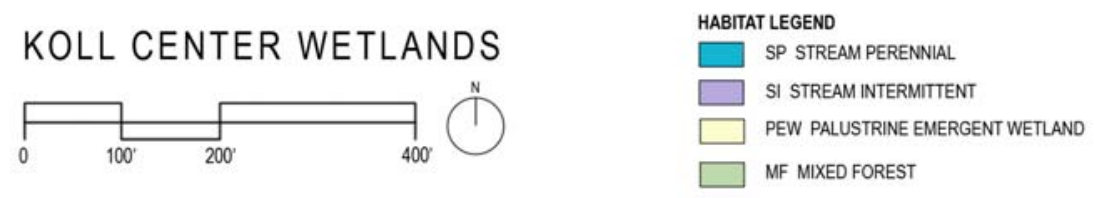

\section{Back to Top}

PHYSICAL ASSETS LEGEND

- SIGN

+ BIRD BOX

$\angle$ SANITARY SEWER

STORM SEWER

다 WEIR

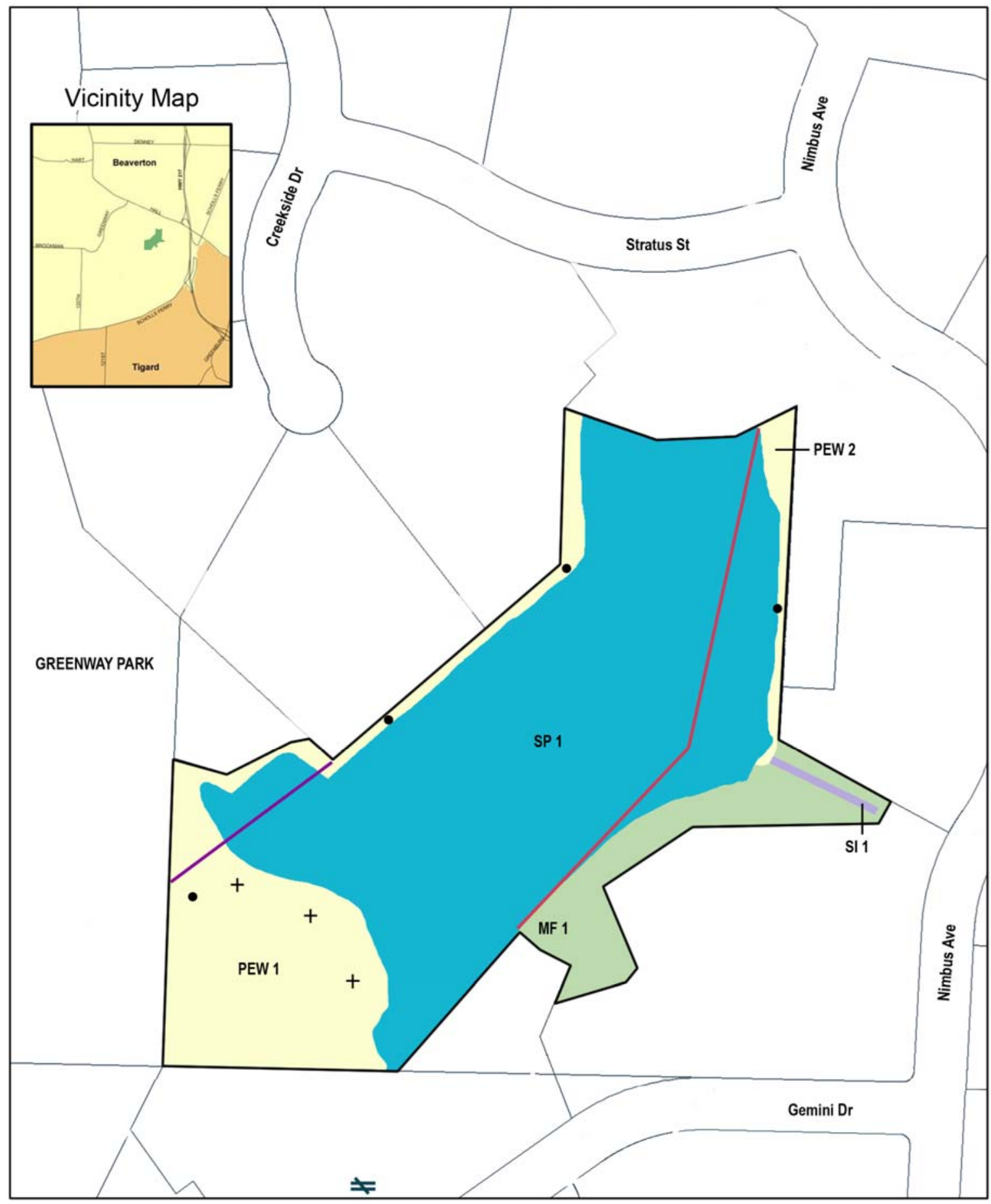


Koll Center Wetlands

November 2006

\section{Appendix C-3 - Enhancement Planting Plan}

\section{Back to Top}
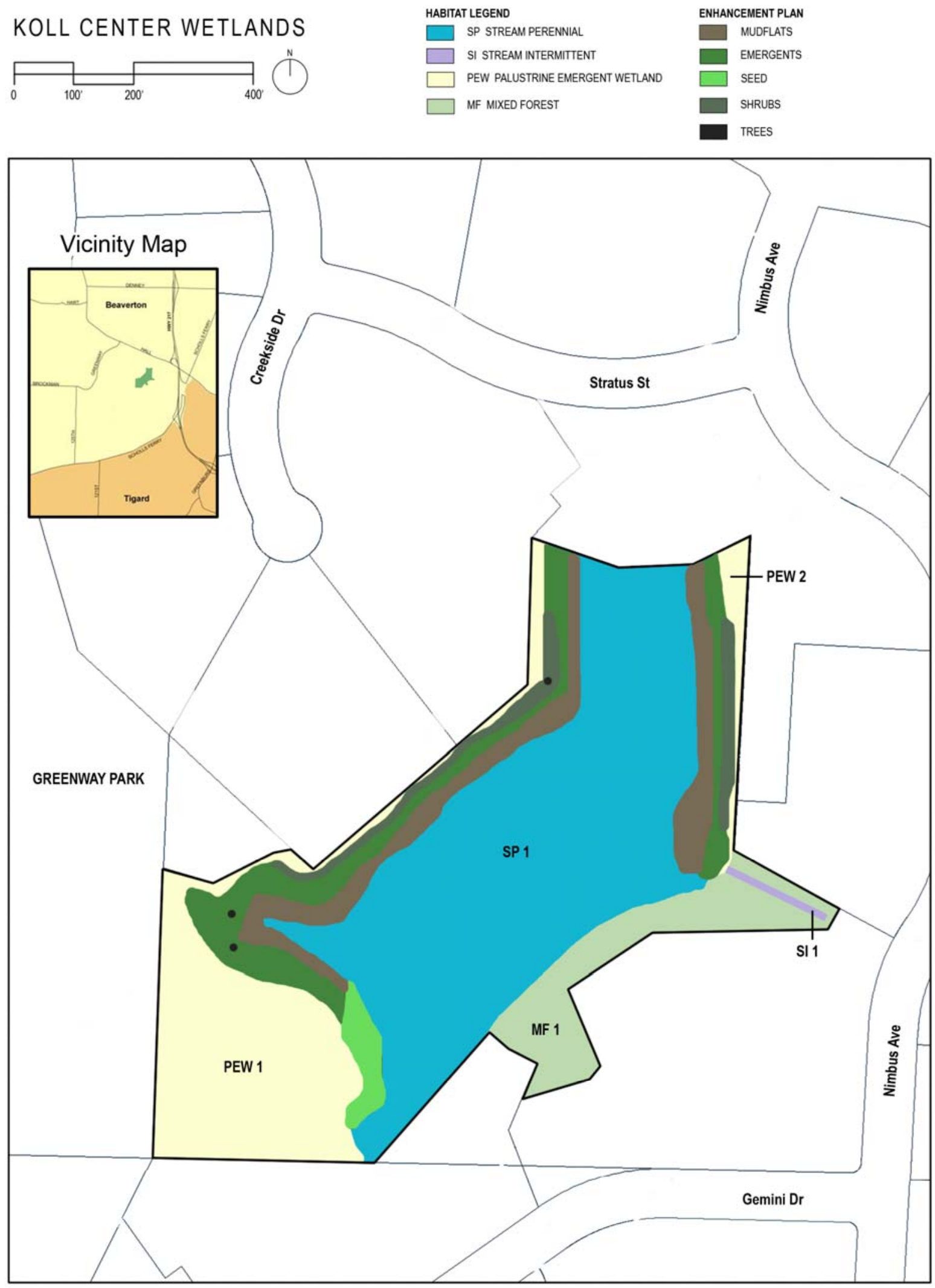
Koll Center Wetlands

November 2006

\section{Appendix C-4 - Blackberry Removal Strategy}

Back to Top
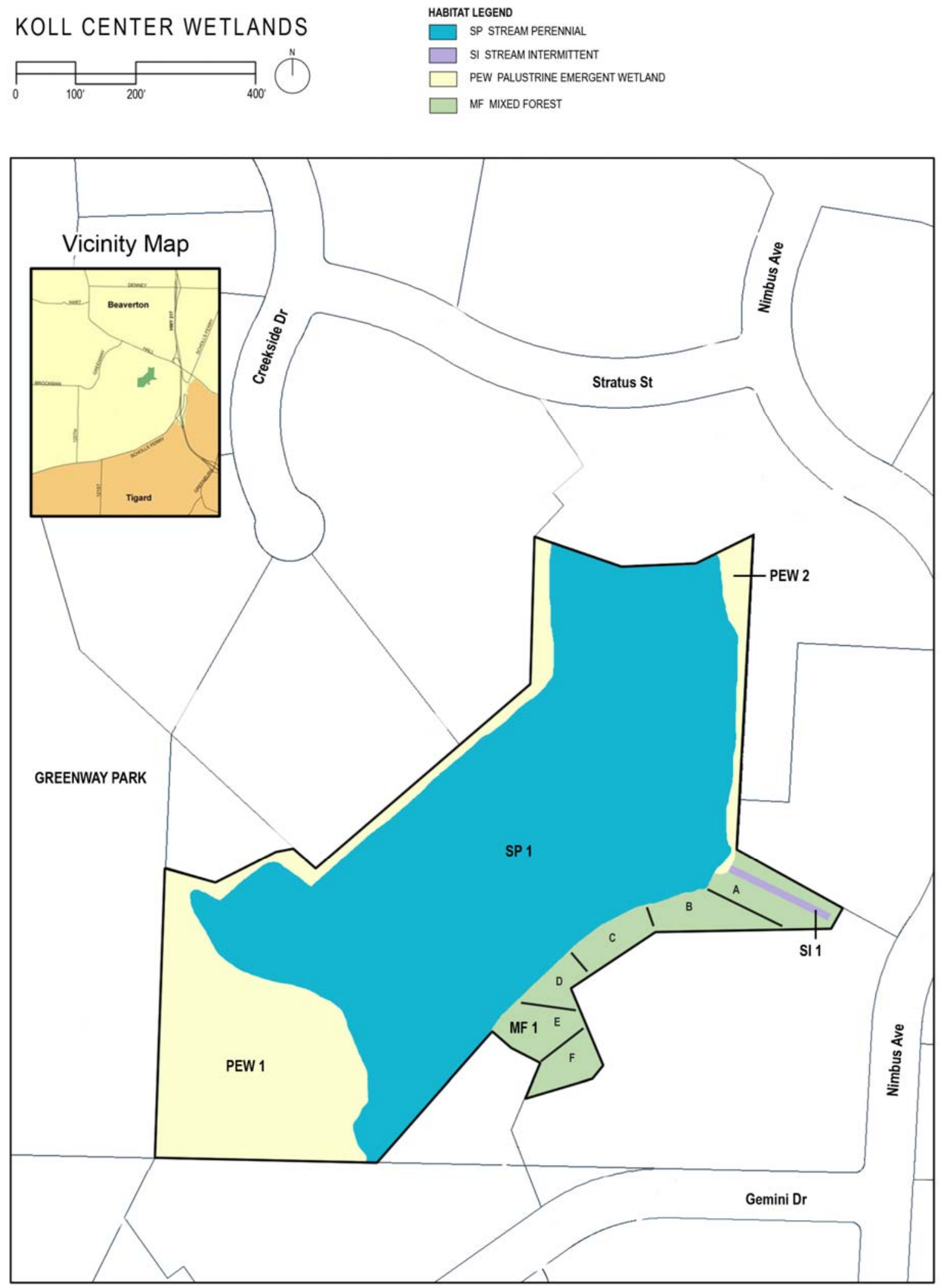
Koll Center Wetlands

November 2006

Appendix D - Activity Spreadsheets

Back to Top 
Koll Center Wetlands

November 2006

\section{$\underline{\text { Appendix E - Best Management Practices }}$}

Back to Top

Please see Best Management Practices on the THPRD Intranet. 